\title{
Eğitim Programları ve Öğretim Alanındaki Araştırma Eğilimleri*
}

\author{
Ceyhun OZAN ${ }^{* *} \quad$ Erdoğan KÖSE ${ }^{* * *}$
}

\begin{abstract}
Özet
Bu çalışmanın amacı Türkiye 'de 2007-2011 yılları arasında "Eğitim Programları ve Öğretim" (EPÖ) alanında yayınlanmış makalelerin incelenerek alandaki araştırma eğilimlerinin belirlenmesidir. Bu temel amaç doğrultusunda, makaleler yayınlandı̆̆ı yıl, yazar sayısı, yöntemi, veri toplama araçları, örneklem özellikleri, veri analiz teknikleri, konu alanları ve konuları açısından değerlendirilmiştir. Makaleler betimsel yaklaşım çerçevesinde doküman incelemesi yapılarak incelenmiş ve her bir makale "Makale Sınıflama Formu" kullanılarak betimsel ve içerik analizine tabi tutulmuştur. Çalışmada ULAKBİM Ulusal Sosyal ve Beşeri Bilimler Veri Tabanında taranan ve EPÖ alanında yayın yapan 24 dergi analiz kapsamına alınmış olup, çalışma 2007-2011 yılları ile sınırlandırılmıştır. Araştırma sonuçlarına göre makalelerin büyük çoğunluğunun tek ya da iki yazarlı olduğu, nicel çalışmalar olduğu, betimsel tarama türünde olduğu, makalelerde çoğunlukla anket ya da likert tipi ölçeklerin kullanıldığı, lisans öğrencileriyle çalışıldığı ve t-testi ve varyans analizi istatistiklerinin kullanıldığı belirlenmiştir. Ayrıca incelenen makalelerin yarıdan fazlasının öğrenme, öğretme, öğrenci-öğretmen özellikleri, öğretmen yetiştirme ve program değerlendirme konu alanlarında yapıldı̆̆ı sonucuna ulaşılmıştır.
\end{abstract}

Anahtar Kelimeler: Eğitim programları ve öğretim, araştırma eğilimleri, bilimsel araştırma, içerik analizi

\section{Research Trends in Curriculum and Instruction}

\begin{abstract}
The purpose of this study is to find out research trends in the field of "Curriculum and Instruction" (CI) in Turkey by exploring the articles that were published between 2007 and 2011. For the purpose, articles were evaluated in terms of their publishing dates, number of authors, methods, data collection procedures, sample characteristics, data analysis techniques, subject areas and their topics. The articles were explored by investigating the documents within the framework of descriptive approach and research trends in the field of CI were attempted to be described. In the study, 24 journals that are published in the field of $\mathrm{CI}$, which are all included in the ULAKBIM Database, were covered in the study. According to results it was determined that the majority of the articles were written either by a single author or two authors, used quantitative research method, descriptive studies, used questionnaires and likert type scale, studied with graduate students and used t-test and variance analysis.
\end{abstract}

Keywords: Curriculum and instruction, research trends, scientific research, content analysis

\footnotetext{
* Bu çalışma 27-29 Eylül 2012 tarihinde Bolu `da düzenlenen 2. Ulusal Eğitim Programları ve Öğretim Kongresi `nde sözlü bildiri olarak sunulmuş ve bildiri özet kitapçı̆̆ında basılmıştır.

** Arş. Gör., Atatürk Üniversitesi, ozanceyhun@atauni.edu.tr

*** Doç. Dr., Atatürk Üniversitesi, erdogank@atauni.edu.tr
} 


\section{Gíriş}

Bilim alanlarında yürütülen akademik çalışmalarda yeni fikirler ve tartışmalar üretilerek, bilgiler paylaşılır ve akademik iletişim sağlanır. Her bilim dalı ya da disiplin geçerli ve güvenilir bilgi üretmeye çalışır (Tavşancıl ve diğerleri, 2010). Staton-Spicer ve Wulff (1984) bir çalışma alanını tanımlamanın en uygun yolunun, o alanın araştırmalarını incelemek olduğunu, her disiplinin kendi ürünlerini periyodik olarak inceleme gereği ve zorunluluğu olduğunu belirtmektedirler. Cohen, Manion ve Morrison (2007) herhangi bir disiplinde yapılan araştırmaların incelenmesi üzerine yapilan çalışmaların ilgili alanda araştırma yapmak isteyenlere yol göstereceğini belirtmişlerdir.

Bilimsel araştırma sonuçlarının sentezlenmesi daha sonraki bilimsel araştırma, politika ve uygulamaları etkiler. Bu sentezler uygulamalar için deneysel bir temel oluşturur ve mesleki etkinliklerde uygulayıcılara rehber niteliğinde de kullanılır. Eğitim alanındaki araştırma sonuçları ise, ders kitapları, ansiklopediler ve el kitapları şeklinde yayınlanan çalışmalar açısından önemli bir içerik kaynağını oluşturur ve herhangi bir öğretim alanında üretilmiş bilgi olarak da kendisini gösterebilir (Dunkin, 1996). Herhangi bir disiplinde yapılan araştırmaların incelenmesiyle o disiplindeki araştırma eğilimleri belirlenebilir. Araştırma eğilimi, araştırmaların zaman içerisinde gösterdikleri değişimi ve bu değişimin yönünü ifade etmektedir. Araştırma eğilimleri belirlenirken, temel alınan yılı izleyen yıllardaki verilerin, temel alınan yıla göre göstermiş oldukları eğilimler incelenir. Araştırma eğilimlerini belirlemeye yönelik çalışmalar gelecekteki olayları öngörmek amacıyla kullanılabileceği gibi araştırılan disiplinin geçmişteki durumunu ortaya koymak amacıyla da kullanılabilir. Başka bir deyişle, ele alınan zaman aralığı çerçevesinde elde edilen veriler kullanılarak, araştırılan disiplinin geçmişteki durumu tahmin edilmeye ya da gelecekteki durumu öngörülmeye çalışılır.

Lee, Wu ve Tsai (2009) araştırmacılar için, alanlarındaki güncel durum ve araştırma eğilimleri hakkındaki bilgilerin kariyerlerinde ve akademik yayınlarında yardımcı olacağını belirtmişlerdir. Keselman vd. (1998) ile Chang, Chang ve Tseng (2010) araştırma eğilimlerini belirlemeye yönelik olarak yapılan çalışmaların alandaki gelecek çalışmaların bir rehberi niteliğinde olabileceğini belirtmişlerdir. Falkingham ve Reeves (1998) da okuyuculara yardımc1 olmak için belirli alanlarda yayınlanan çalışmaların içerik analizi ile incelenmesini önermektedir.

Türkiye de bilimsel araştırma eğilimlerini belirlemeye yönelik farklı disiplinlerde pek çok çalışma yapılmıştır. Alper ve Gülbahar (2009), Gülbahar ve Alper (2009), Göktaş ve diğerleri (2012b) ile Sert, Kurtoğlu, Akıncı ve Seferoğlu (2012) eğitim teknolojilerinde; Apaydın (2009) fizik eğitiminde; Arık ve Türkmen (2009), Karadağ (2009), Tavşancil ve diğerleri (2010) ile Erdem (2011) eğitim bilimlerinde; Balcı ve Apaydın (2009), Aydın, Erdağ ve Sarıer (2010), Aypay vd. (2010) ile Aydın ve Uysal (2011) eğitim yönetiminde; Çalık, Ünal, Coştu, ve Karataş (2008) ile Sözbilir ve Kutu (2008) fen eğitiminde; Kayhan ve Özgün-Koca (2004), Ulutaş ve Ubuz (2008), Baki, Güven, Karataş, Akkan ve Çakıroğlu (2011), Yücedağ ve Erdoğan (2011) ile Çiltaş, Güler ve Sözbilir (2012) matematik eğitiminde; Göktaş ve diğerleri (2012a) eğitim araştırmalarında; İncekara (2009) coğrafya eğitiminde; Küçükoğlu, Taşgın, Ozan ve Kaya (2011) sınıf öğretmenliğinde; Tarman, Güven ve Aktaşlı (2011) sosyal bilgiler eğitiminde Yllmaz ve Altınkurt (2012) okul öncesi eğitiminde makale ya da tezleri inceleyerek alanlarındaki araştırma eğilimlerinin belirlenmesine yönelik çalışmalar yapmışlardır. 
Arık ve Türkmen (2009), Türkiye'de yayımlanmakta olan ve Social Science Citation Index (SSCI)'de taranan eğitim bilimleri ile ilgili dergilerde yer alan makaleleri inceledikleri ve içerik analizine tabi tuttukları çalışmalarında en fazla eğitim teknolojisi alanında makale yayınlandığını ve betimsel araştırmaların ağırlıkta olduğunu belirtmişlerdir. Erdem (2011) de Türkiye'de eğitim alanında 2005-2006 yılları arasında yayımlanmış olan ve Ulakbim Ulusal indeks tarafindan dizinlenen dergilerde yer alan 314 makaleyi incelediği ve betimsel analize tabi tuttuğu çalışmasında, makalelerin çoğunluğunun (\% 56) betimsel araştırma türünde olduğunu ve olasılığa dayalı olmayan örnekleme tekniklerinin \% 55 düzeyinde kullanıldığını saptamıştır. Ayrıca, veri çözümleme tekniği olarak betimsel analizlerin, t-testi ve varyans analizinin \% 58 düzeyinde kullanıldığını ortaya çıkarmıştır. Göktaş ve diğerleri (2012) ise eğitim araştırmaları ile ilgili 5 i SSCI, 14 ü ULAKBİM de taranan toplam 19 dergide yayınlanmış 2115 makaleyi inceledikleri çalışmalarında araştırmaların çoğunun eğitim teknolojileri, fen eğitimi, rehberlik ve psikolojik danışma ve matematik eğitimi disiplinlerinde yapıldığını, araştırmalarda yaygın olarak nicel yöntemlerin ve nicel veri analiz tekniklerinin kullanıldığını, daha çok betimsel analizlerin yapıldığını, örneklem olarak daha çok lisans öğrencileri ve öğretmenlerle çalışıldı̆̆ını belirlemişlerdir. Ayrıca, SSCI ve ULAKBIM'de taranan dergiler arasında belirtilen özelliklerle ilgili olarak anlamlı bir farklılı̆̆ın olmadığı sonucuna ulaşmışlardır.

Eğitim Programları ve Öğretim (EPÖ) alanına özgü olarak araştırma eğilimlerini belirlemeye yönelik çok az sayıda çalışma bulunmaktadır. $\mathrm{Bu}$ çalışmalar EPÖ ana bilim dalındaki lisansüstü tezlerin incelenmesine yöneliktir. Altın (2004) EPÖ alanında yapılmış olan yüksek lisans tezlerini incelemiştir. Çalışma kapsamında Ankara, Gazi ve Hacettepe Ün- iversitelerinde 1985-2002 yılları arasında yapılan ve ulaşılabilen 397 tez yer almıştır. Araştırma bulgularına göre, hazırlanan tez konularının "ilk ve ortaöğretim" kademesinde yoğunlaştığı, "Program Geliştirme" ve "Program Değerlendirme" çalışmalarına yeteri kadar yer verilmediği, tezlerin deneysel yöntemlerden çok betimsel yöntemlerle yapıldığı belirlenmiştir.

Bıkmaz ve diğerleri (2010) Türkiye de program geliştirme alanında 2009 yılına kadar yapılmış olan 251 doktora tezini incelemişlerdir. Araştırma sonuçlarına göre araştırmalarda çoğunlukla “öğrenme öğretme yaklaşımlarının başarı ve tutuma etkileri”, "öğrenme stilleri ve stratejilerinin kullanımı", "öğretmen yetiştirme" ve "örgün eğitim programlarının değerlendirilmesi" konularının araştırıldı̆̆ı, araştırmaların ağırlıklı olarak "ilköğretim ve yükseköğretim programları"na odaklandığı belirlenmiştir. On yıllık dilimler halinde yapılan incelemelerde ise program geliştirme alanında yapılan doktora tezlerinin sayılarının katlanarak arttığı, deneysel ve betimsel çalışmaların çok daha fazla tercih edildiği, diğer taraftan betimsel ve deneysel araştırmaların sayıca birbirine çok yakın olduğu bulunmuştur.

Saracaloğlu ve Dursun (2010) da Türkiye'deki EPÖ anabilim dalında yüksek lisans ve doktora tezlerindeki araştırma eğilimlerini belirlemeyi amaçlamışlardır. Bu kapsamda 59 yüksek lisans ve 13 doktora tezini incelemişlerdir. Araştırmanın sonucunda tezlerdeki çalışma konularının, daha çok “ders programları", "öğrenme yaklaşımları", "bilgisayar ve teknoloji", "öğrenme stilleri" ve "öğrenme stratejileri" ile ilgili olduğu görülmüştür. Tezlerde kullanılan araştırma modellerinin ise sirasiyla tarama ve deneysel model kullanıldığı, bunu karma model ve nitel modelin izlediği belirlenmiştir. Uygulama yapılan 
gruplara bakıldığında, sırasıyla en çok ilköğretim öğrencileri, öğretmenler, üniversite öğrencileri, lise öğrencileri ve öğretim elemanlarıyla çalışıldığı belirlenmiştir. Tezlerde en çok anket, başarı testi, kişisel bilgi formu, tutum ölçeği, ön test, son test gibi veri toplama araçlarıyla bilgi toplandığı saptanmıştır. Nicel veri analizlerinde genellikle merkezi dağılım ve değişkenlik ölçüleri gibi betimsel istatistiksel teknikler kullanıldığı; nitel veri analizlerinde ise, içerik analizi ve betimsel analiz olmak üzere iki temel analiz tekniğinin kullanıldığı belirlenmiştir.

Bu çalışmalar Türkiye de "Eğitim Programları ve Öğretim" alanında yapılan tezlerdeki araştırma eğilimlerini ortaya koymaktadır. Ancak yapılan alanyazın incelemesinde Türkiye'de "Eğitim Programları ve Öğretim" alanında yapılan makalelerin incelenmesi ve araştırma eğilimlerinin belirlenmesine yönelik herhangi bir çalışmaya rastlanmamıştır. Bu anlamda bu çalışmanın alanyazındaki bir boşluğu doldurması beklenmekte ve "Eğitim Programları ve Öğretim" alanındaki araştırma eğilimlerinin belirlenmesi açısından önemli olduğu düşünülmektedir. EPÖ alanındaki araştırma eğilimlerinin belirlenmesi, alanın genel karakterini ortaya koyması bakımından önem taşımaktadır. EPÖ alanındaki güncel bilimsel makalelerin incelenerek baskın olan konu alanları, konular, yöntemler veya örneklem özelliklerinin belirlenmesi, alanda çalı̧̧ma yapmayı düşünen akademisyenlere, lisansüstü öğrencilere ya da araştırmacılara yön verebilir. Özellikle, yüksek lisans veya doktora aşamalarında araştırma konusuna karar vermekte zorlanan öğrencilerin alanda sık çalışılmış güncel konuları veya az çalışılmış konuları görmelerine imkan sağlayarak rehber niteliğinde olabilir.

EPÖ alanının bir bilim dalı olarak sınırlarını çizmek oldukça zordur. Hangi çalışmaların
EPÖ alanının kapsamında ele alınabileceği ya da alınamayacağı konusunda net bir bilgi mevcut değildir. Bu açıdan, bu çalışmada, EPÖ alanında yayınlanmış makalelerin belirlenmesi amacıyla Eğitim Programları ve Öğretim Ana Bilim Dalı̀nda görev yapan ya da o alanda doktora yapmış olan öğretim elemanları veya araştırmacıların yayınlamış olduğu makaleler çalışma kapsamına alınmıştır. Bu kapsamda, bu çalışmanın amacı Türkiye'de 2007-2011 yılları arasında "Eğitim Programları ve Öğretim" alanında yayınlanmış makalelerin incelenerek alandaki güncel araştırma eğilimlerinin belirlenmesidir. $\mathrm{Bu}$ temel amaç doğrultusunda, makaleler yayınlandığı yıl, yazar sayısı, yöntemi, veri toplama araçları, örneklem özellikleri, veri analiz teknikleri, konu alanları ve konuları açısından değerlendirilmiştir.

\section{YÖNTEM}

\section{Araştırma Modeli}

$\mathrm{Bu}$ araştırmada nitel araştırma yöntemi kullanılmıştır. Nitel yöntem çerçevesinde doküman incelemesi yapilarak makaleler incelenmiş ve EPÖ alanındaki araştırma eğilimleri betimlenmeye çalışılmıştır.

\section{Örneklem}

Çalışmada ULAKBIM Ulusal Sosyal ve Beşeri Bilimler Veri Tabanında taranan ve EPÖ alanında yayın yapan 24 dergi analiz kapsamına alınmış olup, çalışma 2007-2011 yılları ile sinırlandırılmıştır. Çalışma EPÖ alanındaki güncel araştırma eğilimlerini belirlemeyi amaçladığından son beş yılda yayınlanan makaleler incelenmiştir. 24 dergi içerisinde yer alan ve Eğitim Programları ve Öğretim Ana Bilim Dalı̀nda görev yapan ya da o alanda doktora yapmış olan öğretim elemanları veya araştırmacıların yayınlamış olduğu toplam 380 makale incelenmiştir. EPÖ’de doktora yapana araştırmacıların belirlenmesi için YÖK tez veritabanından ЕPÖ bilim ya da ana bilim dalında doktora yapanlar listelenmiş, EPÖ ana bilim 
dalında çalışanların belirlenmesi amacıyla da her üniversitenin internet sayfasindan yararlanılarak EPÖ'de görev yapan öğretim elemanlarının listesi çıkarılmıştır. Makalelerin çalışma kapsamına dahil edilmesinde bu listelerden yararlanılmıştır. Çok yazarlı makalelerde, yazarlardan birinin EPÖ alanında doktora yapmış olması makalenin çalışma kapsamına dâhil edilmesi için yeterli görülmüştür. Ayrıca internet ortamında tam metin olarak ulaşılamayan dergi veya makaleler kapsam dışında bırakılmıştır. İncelenen dergiler ve makale sayıları Ek 1 'de gösterilmiştir.

\section{Veri Toplama Aracı}

Her bir makale "Makale Siniflama Formu" kullanılarak içerik analizine tabi tutulmuştur. "Makale Sinıflama Formu" Sözbilir ve Kutu (2008) tarafından geliştirilmiş olup bu çalışmada revize edilerek kullanılmıştır. Formun geliştirilmesinde McMillan ve Schumacher'in (2006) yöntem/desen sinıflamaları dikkate alınmıştır (Sözbilir ve Kutu (2008). Revize edilen formun kapsam geçerliğini sağlamak amacıyla form, EPÖ alanında öğretim üyesi olan 3 uzman tarafından incelenmiştir. Uzmanlar arasındaki tutarlılığın belirlenmesinde Cohen Kappa uyum katsayısı hesaplanmış ve formun geneli için 0.83 bulunmuştur. Kappa katsayısı 0.40 ile 0.75 arasında ise kabul edilebilir uyuşma, 0.75 ve daha büyük ise mükemmel bir uyuşma olduğu anlamına gelmektedir (Şencan, 2005). Buna göre, formun kapsam geçerliğinin yüksek olduğu sonucuna ulaşılmıştır. Form, temel olarak beş bölümden oluşmaktadır: Makalenin künyesi, araştırma deseni/yöntemi, veri toplama araçları, örneklem ve veri analiz yöntemleri. Veri toplama aracı Ek 2 'de sunulmuştur.

\section{Verilerin Analizi}

Elde edilen verilerin çözümlenmesinde nitel analiz tekniklerinden betimsel ve içerik analizi teknikleri bir arada kullanılmıştır. Betimsel analizde, elde edilen veriler daha önceden belirlenen temalara göre özetlenir. İçerik analizinde ise birbirine benzeyen verileri belirli kavramlar ve temalar çerçevesinde bir araya getirmek ve bunları okuyucunun anlayabileceği bir biçimde düzenleyerek yorumlamaktır (Yıldırım ve Şimşek, 2011). Bu araştırmada da her bir makale "Makale Sinıflama Formu" kullanılarak incelenmiş ve ardından SPSS programına kaydedilmiştir. Makale Sınfflama Formu'nun makalenin künyesi, araştırma deseni/yöntemi, veri toplama araçları, örneklem ve veri analiz teknikleri kısımları betimsel analiz ile incelenmiştir. Her bir makale formda yer alan ve önceden belirlenmiş kategorilere göre sinıflandırılmıştır. Makalenin konusu kısmı için ise içerik analizi tekniği kullanılmıştır. Her bir makalenin konusuna göre kategori ve alt kategoriler oluşturulmuştur. Veri analizlerinin güvenirliğini sağlamak adına rastgele seçilen 38 makale her iki araştırmacı tarafından bağımsız olarak incelenmiş ve analizler arasında karşılaştırma yapılmıştır. Karşılaştırmalar sonucunda analizlerin birbirine çok yakın olduğu belirlenmiş, kategori ve alt kategorilerin oluşturulmasında fikir birliğine varılmıştır. Bu aşamadan sonra diğer makalelerin incelemesi birinci araştırmacı tarafından yapılmış, analizlerde tereddüte düşüldüğü durumlarda EPÖ alanında daha fazla deneyime ve bilgi birikimine sahip olan ikinci yazarın görüşlerine başvurulmuştur. Analiz sonuçları frekans ve yüzde değerleri ile ifade edilmiştir.

\section{BULGULAR}

2007-2011 yılları arasında EPÖ alanında yayınlanmış makalelerin incelenerek alandaki araştırma eğilimlerinin belirlenmesi amacıyla 24 dergi içerisinde yer alan toplam 380 makale betimsel ve içerik analizine tabi tutulmuştur. Makalelerin yayınlanma yılına ilişkin frekans ve yüzde değerleri Tablo 1'de verilmiştir. 
Tablo 1. Makalelerin Yayınlandığ $\mathrm{Y}_{1} 1$

\begin{tabular}{|c|c|c|c|c|c|}
\hline Kategori & $\mathrm{f}$ & $\%$ & Kategori & $\mathrm{f}$ & $\%$ \\
\hline 2007 & 69 & 18.2 & 2010 & 80 & 21.1 \\
\hline 2008 & 67 & 17.6 & 2011 & 78 & 20.5 \\
\hline 2009 & 86 & 22.6 & & & \\
\hline Toplam & 380 & 100 & & & \\
\hline \multicolumn{3}{|c|}{$\begin{array}{l}\text { Makalelerin } 69 ` \text { u (\% 18.2) } 2007 \text { yılında, 67`si (\% } \\
\text { 17.6) } 2008 \text { yılında, } 86 ` s ı \text { (\% 22.6) } 2009 \text { yılında, } \\
80 ` i \text { (\% 21.1) } 2010 \text { yılında ve } 78 ` i \text { (\% 20.5) ise } \\
2011 \text { yılında yayınlanmıştır. EPÖ alanında }\end{array}$} & \multicolumn{3}{|c|}{$\begin{array}{l}\text { yapılan makale sayısının son üç yılda az da } \\
\text { olsa arttığı söylenebilir. Makalelerin yazar } \\
\text { sayısına ilişkin frekans ve yüzde değerleri } \\
\text { Tablo } 2 \text { 'de verilmiştir. }\end{array}$} \\
\hline
\end{tabular}

Tablo 2. Makalelerin Yazar Sayısı

\begin{tabular}{|c|c|c|c|c|c|}
\hline Kategori & $\mathrm{f}$ & $\%$ & Kategori & $\mathrm{f}$ & $\%$ \\
\hline 1 yazarlı & 149 & 39.2 & 4 yazarlı & 6 & 1.6 \\
\hline 2 yazarlı & 173 & 45.5 & 5 yazarlı & 3 & 0.8 \\
\hline 3 yazarlı & 46 & 12.1 & 6 yazarlı & 3 & 0.8 \\
\hline Toplam & 380 & 100 & & & \\
\hline \multicolumn{3}{|c|}{$\begin{array}{l}\text { Yazar sayısına göre incelendiğinde makalelerin } \\
149 ` \text { u (\% 39.2) tek yazarlı, } 173 \text { ü (\% } 45.5) \text { iki } \\
\text { yazarlı, } 46 \text { `sı (\% 12.1) üç yazarlı, 6`sı (\% 1.6) } \\
\text { dört yazarlı, } 3 \text { ü (\% } 0.8 \text { ) beş yazarlı ve } 3 \text { ü (\% }\end{array}$} & \multicolumn{3}{|c|}{$\begin{array}{l}\text { beklentileri ile açıklanabilir. Türkiye de akad- } \\
\text { emik olarak yükselme ve atama kriterlerinde } \\
\text { genellikle tek ya da iki yazarlı makaleler daha } \\
\text { çok puan getirmekte ve itibarlı görülmektedir. }\end{array}$} \\
\hline
\end{tabular}

Tablo 3. Makalelerin Türü

\begin{tabular}{|c|c|}
\hline Kategori & $\%$ \\
\hline Araştırma-inceleme & 89.5 \\
\hline Kuramsal (Derleme) & 10.5 \\
\hline Toplam & 100 \\
\hline $\begin{array}{l}\text { Makalelerin } 340 ` \text { (\% 89.5) araştırma-inceleme } \\
\text { türünde, } 40 ` \text { da (\% 10.5) kuramsal (derleme) } \\
\text { türündedir. EPÖ alanında kuşkusuz, kuramsal } \\
\text { (derleme) çalışmalara da ihtiyaç vardır ancak } \\
\text { araştırma-inceleme türündeki çalışmaların }\end{array}$ & $\begin{array}{l}\text { düşünülürse, araştırmalarının büyük çoğunluk- } \\
\text { ta araştırma-inceleme türünde olmasının } \\
\text { olumlu olduğu söylenebilir. Makalelerin } \\
\text { araştırma yöntemine ilişkin frekans ve yüzde } \\
\text { değerleri Tablo } 4 \text { te verilmiştir. }\end{array}$ \\
\hline
\end{tabular}


Tablo 4. Makalelerin Deseni/Yöntemi

\begin{tabular}{|c|c|c|c|c|}
\hline & Araştırma Deseni & Araştırma Yöntemi & $\mathrm{f}$ & $\%$ \\
\hline \multirow{9}{*}{ 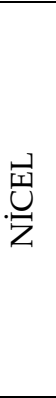 } & \multirow{5}{*}{ Deneysel } & Gerçek deneysel & 4 & 1.18 \\
\hline & & Yarı deneysel & 43 & 12.65 \\
\hline & & Zayıf deneysel & 3 & 0.88 \\
\hline & & Tek denekli & 1 & 0.29 \\
\hline & & Ara toplam & 51 & 15.00 \\
\hline & \multirow{4}{*}{ Deneysel Olmayan } & Betimsel tarama & 205 & 60.29 \\
\hline & & İlişkisel tarama & 21 & 6.17 \\
\hline & & Karşılaştırmalı & 0 & 0 \\
\hline & & Ara toplam & 226 & 66.47 \\
\hline \multirow{14}{*}{ 毁 } & \multirow{8}{*}{ Etkileşimli } & Kültür analizi & 0 & 0 \\
\hline & & Olgubilim & 4 & 1.18 \\
\hline & & Kuram oluşturma & 0 & 0 \\
\hline & & Durum çalışması & 10 & 2.94 \\
\hline & & Eleştirel çalışma & 0 & 0 \\
\hline & & Eylem araştırması & 1 & 0.29 \\
\hline & & Diğer & 1 & 0.29 \\
\hline & & Ara toplam & 16 & 4.71 \\
\hline & \multirow{6}{*}{ Etkileşimsiz } & Kavram analizi & 0 & 0 \\
\hline & & Tarihsel analiz & 0 & 0 \\
\hline & & Meta analiz & 2 & 0.59 \\
\hline & & Diğer & 1 & 0.29 \\
\hline & & Ara toplam & 3 & 0.88 \\
\hline & & Türü belirtilmemiş & 21 & 6.18 \\
\hline \multirow{5}{*}{ 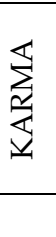 } & \multirow{5}{*}{ Karma } & Açıklayıcı & 2 & 0.59 \\
\hline & & Keşfedici & 1 & 0.29 \\
\hline & & Çeşitleme & 20 & 5.88 \\
\hline & & Ara toplam & 23 & 6.76 \\
\hline & & Toplam & 340 & 100 \\
\hline
\end{tabular}

Makalelerin 277`si (\% 81.5) nicel, 40 i (\% 11.8) nitel ve 23 ü (\% 6.8) de karma yönteme sahiptir. Deneysel desende olan nicel makalelerin 43 ü (\% 12.9) yarı deneyseldir. Deneysel olmayan nicel makalelerin $105 \mathrm{i}$ (\% 60.3) ise betimsel taramadır. Etkileşimli desendeki nitel makalelerin 10 'u (\% 2.9) durum çalışması, etkileşimli olmayan desendeki nitel makalelerin ise 2`si (\% 0.6) meta analiz türündedir. Karma desendeki çalışmaların 20`si de (\% 5.9) çeşitleme türündedir. Karşılaştırmalı türde, kuram oluşturma, kültür analizi ve eleştirel çalışma türünde, kavram analizi ya da tarihsel analiz türünde herhangi bir araştırma bulunmamaktadır. Alandaki çalışmaların çoğunluğu betimsel ya da ilişkisel tarama türündedir. Bu durum EPÖ alanındaki makalelerin daha çok var olan durumu ortaya çıkarmaya yönelik olduğunu göstermektedir. Olayları derinlemesine inceleme olanağı veren nitel çalışmaların, neden sonuç ilişkisine dayalı deneysel çalışmaların ve hem nicel hem de nitel yöntemlerin bir arada kullanılarak her iki yöntemin sınırlılıklarını azaltan karma yöntemin yeterince işe koşulmadiğı söylenebilir. Araştırmaincelemeye dayalı olan 340 makalenin veri toplama teknikleri ve araçlarına ilişkin frekans değerleri Tablo 5 te verilmiştir. Bir makalede birden fazla veri toplama tekniği ya da aracı kullanılabileceğinden yüzde değerleri hesaplanmamıştır. 
Tablo 5. Makalelerin Veri Toplama Araçları

\begin{tabular}{|c|c|c|c|c|c|}
\hline Kategori & Alt kategori & $\mathrm{f}$ & Kategori & Alt kategori & $\mathrm{f}$ \\
\hline \multirow{4}{*}{ Gözlem } & Katılımc1 & 3 & \multirow{4}{*}{ Anket/Ölçek } & Açık uçlu & 26 \\
\hline & Katılımcı olmayan & 12 & & Likert tipi & 221 \\
\hline & Belirtilmemiş & 1 & & Diğer & 24 \\
\hline & Toplam & 16 & & Toplam & 263 \\
\hline \multirow{6}{*}{ Görüşme Formu } & Yapılandırılmış & 1 & \multirow{6}{*}{ Dokümanlar } & & \multirow{6}{*}{17} \\
\hline & Yarı yapılandırılmış & 40 & & & \\
\hline & Yapılandırılmamış & 0 & & & \\
\hline & Odak grup & 2 & & & \\
\hline & Belirtilmemiş & 2 & & & \\
\hline & Toplam & 45 & & & \\
\hline \multirow{4}{*}{ Başarı testi } & Açık uçlu & 4 & & & \multirow{4}{*}{16} \\
\hline & Çoktan seçmeli & 45 & $\begin{array}{l}\text { Tamamlayıcı } \\
\text { (Alternatif) } \\
\text { değerlendirme }\end{array}$ & & \\
\hline & Diğger & 5 & & & \\
\hline & Toplam & 54 & & & \\
\hline \multirow{4}{*}{$\begin{array}{l}\text { Yetenek/Kişilik } \\
\text { testi }\end{array}$} & Açık uçlu & 0 & \multirow{4}{*}{ Diğer } & & \multirow{4}{*}{8} \\
\hline & Çoktan seçmeli & 1 & & & \\
\hline & Diğer & 4 & & & \\
\hline & Toplam & 5 & & & \\
\hline \multicolumn{2}{|c|}{$\begin{array}{l}\text { Araştırma-incelemeye dayalı olan makaleler } \\
\text { veri toplama teknikleri ve araçları açısından } \\
\text { incelendiğinde makalelerde en çok anket/ölçek } \\
\text { ( } \mathrm{f}=263 \text { ) ve başarı testi ( } \mathrm{f}=54 \text { ) kullanıldığ } 1 \\
\text { görülmektedir. Kullanılan anket/ölçeklerin } \\
\text { büyük çoğunluğu ( } \mathrm{f}=221 \text { ) likert tipindedir. } \\
\text { Başarı testlerinin büyük çoğunluğu (f= 45) } \\
\text { çoktan seçmeli sorulardan oluşmaktadır. } \\
\text { Görüşmelerin büyük çoğunluğu (f= 40) yarı } \\
\text { yapılandırılmış formlarla yapılmıştır. }\end{array}$} & & \multicolumn{3}{|c|}{$\begin{array}{l}\text { olmayan gözlem türündedir. } 8 \text { makalede ise } \\
\text { form ya da liste şeklindeki araçlar } \\
\text { kullanılmıştır. Makalelerin çoğunluğunun } \\
\text { tarama türündeki çalışmalar olması nedeniyle } \\
\text { anket veya ölçeklerin en çok kullanılan araçlar } \\
\text { olmaları beklenilen bir sonuç olarak yorumlan- } \\
\text { abilir. Makalelerin örneklem gruplarına ilişkin } \\
\text { frekans değerleri Tablo 6`da verilmiştir. Bir } \\
\text { makalede birden fazla örneklem grubu yer } \\
\text { alabileceğinden yüzde değerleri }\end{array}$} \\
\hline
\end{tabular}

Tablo 6. Makalelerin Örneklem Grupları

\begin{tabular}{lclc}
\hline Kategori & $\mathrm{f}$ & Kategori & $\mathrm{f}$ \\
\hline Okul öncesi & 1 & Öğretmenler & 85 \\
\hline İlkokul & 42 & Yöneticiler & 6 \\
\hline Ortaokul & 33 & Veliler & 9 \\
\hline Ortaöğretim & 16 & Ö̈̆retim elemanları & 7 \\
\hline Lisans & 163 & Müfettişler & 1 \\
\hline Lisansüstü & 8 & Diğer & 1 \\
\hline
\end{tabular}

Örneklem grupları incelendiğinde makalelerde en çok lisans öğrencileri ( $f=163$ ) ve öğretmenler $(\mathrm{f}=85)$ ile çalışıldığ görülmektedir. Buna göre, EPÖ alanındaki makalelerin öğretmen yetiştirmeye odaklandığı söylenebilir. Bu du- ruma lisans öğrencilerinden veri elde etmenin zaman ve emek açısından ekonomik olmasının etkili olduğu söylenebilir. Makalelerin örneklem büyüklüklerine ilişkin frekans ve yüzde değerleri Tablo 7 'de verilmiştir. 
Tablo 7. Makalelerin Örneklem Büyüklükleri

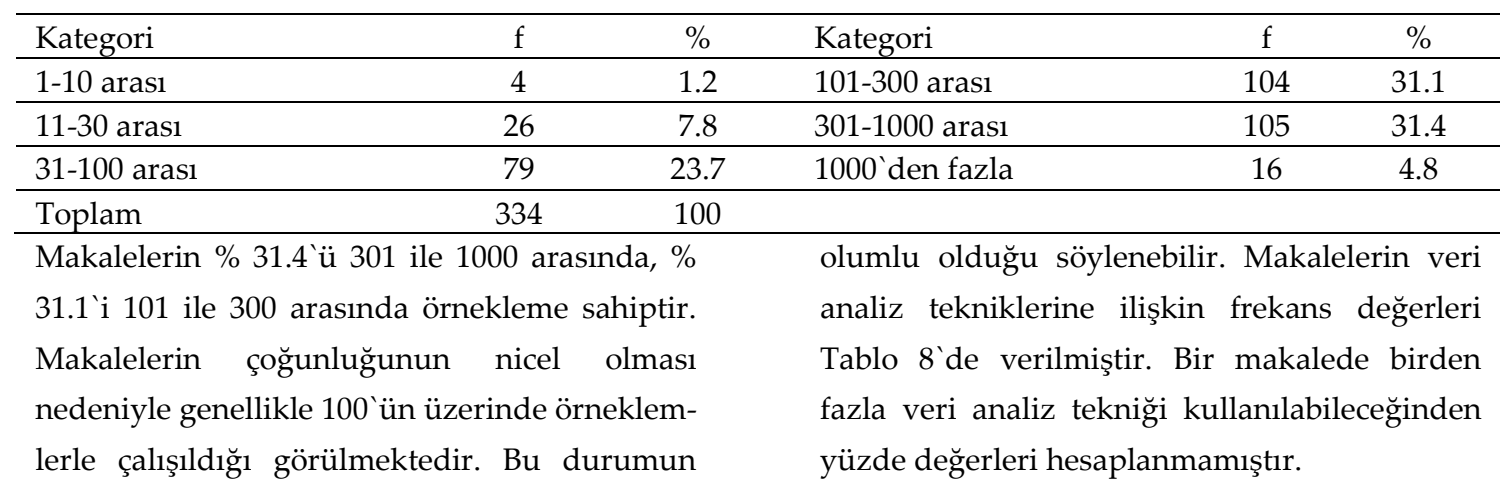

Tablo 8. Makalelerin Veri Analiz Teknikleri

\begin{tabular}{|c|c|c|}
\hline Kategori & Alt kategori & $\mathrm{f}$ \\
\hline \multirow{4}{*}{ Betimsel } & Frekans/yüzde & 140 \\
\hline & Ortalama/Standart sapma & 239 \\
\hline & Grafikle gösterim & 11 \\
\hline & Toplam & 282 \\
\hline \multirow{12}{*}{ Kestirimsel } & Korelasyon Analizi & 42 \\
\hline & t-testi & 183 \\
\hline & ANOVA (Varyans analizi) & 138 \\
\hline & ANCOVA (Kovaryans analizi) & 14 \\
\hline & MANOVA (Çok değişkenli varyans analizi) & 4 \\
\hline & MANCOVA (Çok değişkenli kovaryans analizi) & 1 \\
\hline & Faktör Analizi & 57 \\
\hline & Regresyon Analizi & 12 \\
\hline & Non-Parametrik Testler & 60 \\
\hline & Yapısal Eşitlik Modeli & 1 \\
\hline & Diğer (Rasch analizi, Bağlantı analizi) & 1 \\
\hline & Toplam & 255 \\
\hline \multirow{4}{*}{ Nitel } & İçerik analizi & 43 \\
\hline & Betimsel analiz & 17 \\
\hline & Diğer & 3 \\
\hline & Toplam & 63 \\
\hline
\end{tabular}

Veri analiz teknikleri incelendiğinde ise makalelerin 282 sinde betimsel, 255 'inde kestirimsel ve 75 'inde de nitel analiz teknikleri kullanılmıştır. Betimsel analiz yapılan makalelerin 140 `nda frekans/yüzde değerleri, 239 'unda ortalama/standart sapma değerleri hesaplanmıştır. Ayrıca, 11 makalede ise grafikle gösterim yapılmıştır. Kestirimsel analizlerin yapıldığı makalelerde en çok t-testi $(f=183)$, ANOVA ( $f=138)$, non-parametrik testler $(f=60)$, faktör analizi $(\mathrm{f}=57)$ ve korelasyon analizi $(\mathrm{f}=$
42) kullanılmıştır. Nitel analiz teknikleri incelendiğinde ise makalelerin 43 ünde içerik analizi, 17 sinde betimsel analiz ve 3 ünde de diğer nitel analiz tekniklerinin kullanıldığı görülmektedir. Tarama çalışmalarının yoğunlukta olduğu bir alanda ANCOVA, MANOVA ve MANCOVA gibi ileri istatistiki teknikler olarak nitelendirilebilecek testlerin çok az kullanılması alandaki bir eksiklik olarak nitelendirilebilir. Makalelerin konu alanlarına ilişkin frekans değerleri Tablo 9`da verilmiştir. 
Tablo 9. Makalelerin Konu Alanları

\begin{tabular}{lclc}
\hline Kategori & $\mathrm{f}$ & Kategori & $\mathrm{f}$ \\
\hline Öğretme & 95 & Ölçme ve değerlendirme & 17 \\
\hline Öğrenci-öğretmen özellikleri & 69 & Eğitim teknolojileri & 17 \\
\hline Öğrenme & 57 & Eğitim felsefesi & 16 \\
\hline Öğretmen yetiştirme & 32 & Sinıf yönetimi & 11 \\
\hline Program değerlendirme & 29 & Eğitim tarihi & 3 \\
\hline Ĕ̆itim sistemi & 25 & Ölçek geliştirme/uyarlama/sınama & 12 \\
\hline Değerler eğitimi & 22 & & \\
\hline
\end{tabular}

Makalelerin yarıdan fazlası (221) öğretme, öğrenci-öğretmen özellikleri ve öğrenme, konu alanlarında yapılmıştır. Ayrıca 12 makale ölçek geliştirme, uyarlama ya da sınama çalışması şeklindedir. EPÖ alanındaki makalelerin eğitim programlarının öğrenme-öğretme süreci öğesi üzerinde yoğunlaştı̆̆ eğitim felsefesi ve eğitim tarihi gibi alanın temelini oluşturan konu alanlarındaki çalışma sayısının ise az olduğu söylenebilir. Öğretme konu alanına ilişkin frekans değerleri Tablo 10 'da verilmiştir.

Tablo 10. Öğretme Konu Alanı

\begin{tabular}{lcll}
\hline Kategori & $\mathrm{f}$ & Kategori & $\mathrm{f}$ \\
\hline Yapılandırmacılık & 11 & Proje tabanlı öğrenme & 3 \\
\hline Çoklu zekâ & 8 & Plan & 3 \\
\hline Soru sorma & 8 & Harmanlanmış öğrenme & 2 \\
\hline İşbirlikli öğrenme & 5 & Aktif öğrenme & 2 \\
\hline Probleme dayalı öğrenme & 4 & Ödev & 2 \\
\hline Drama & 4 & İlkokuma-yazma öğretimi & 2 \\
\hline Grup çalışmaları & 4 & Mikro öğretim & 2 \\
\hline Dil öğretim yöntemleri & 4 & Yaşam boyu öğrenme & 2 \\
\hline Katlı öğretim & 3 & Bireyselleştirilmiş öğretim & 2 \\
\hline Bilişsel koçluk & 3 & Bilgisayar destekli öğretim & 2 \\
\hline Beyin temelli öğrenme & 3 & Diğer & 16 \\
\hline
\end{tabular}

Tablo 10`a göre öğretme konu alanına göre makaleler incelendiğinde, çok geniş bir yelpazeye yayılmakla birlikte daha çok son dönemde popüler olan öğretme yaklaşımlarının (yapılandırmacılık, çoklu zekâ, işbirlikli öğrenme vb.) çalışıldığı görülmektedir. Türkiye'de 2005 yilında uygulamaya koyulan ilköğretim ve ortaöğretim programlarında önemli yer tutan yapılandırmacılık, çoklu zekâ, işbirlikli öğrenme ve probleme dayalı öğrenme gibi konuların EPÖ alanında da popüler olduğu söylenebilir. Öğrenci-öğretmen özellikleri konu alanına ilişkin frekans değerleri Tablo 11 'de verilmiştir.

Tablo 11. Öğrenci-Öğretmen Özellikleri Konu Alanı

\begin{tabular}{|c|c|c|c|}
\hline Kategori & $\mathrm{f}$ & Kategori & $\mathrm{f}$ \\
\hline Öğretmenlik mesleği tutum/tercih & 14 & Okuma ilgisi & 3 \\
\hline Öğretmen yeterlikleri/özellikleri & 9 & Problem çözme becerisi & 2 \\
\hline Özyeterlik alg1sı/inanc1 & 8 & Görsel okuryazarlık & 2 \\
\hline Yansıtıcı düşünme becerisi & 6 & Bilgisayar/teknoloji okuryazarlığ1 & 2 \\
\hline Medya okuryazarlığ & 4 & Sözlü-yazılı anlatım becerisi & 2 \\
\hline Bilgi okuryazarlığ & 3 & Düşünme stilleri & 2 \\
\hline Eleştirel düşünme becerisi & 3 & Diğer & 9 \\
\hline $\begin{array}{l}\text { Öğrenci-öğretmen özellikleri konu alanı } \\
\text { çerçevesinde en çok öğretmenlik mesleğine }\end{array}$ & & $\begin{array}{l}\text { yönelik tutum/tercih }(\mathrm{f}=14) \text {, öğr } \\
\text { likleri/özellikleri }(\mathrm{f}=9) \text {, özyeterlik a }\end{array}$ & \\
\hline
\end{tabular}


yansıtıcı düşünme becerisi $(\mathrm{f}=6)$ konuları çalışılmıştır. Türkiye 'de öğretmenlik mesleği ile ilgili sıklıkla yaşanan değişikliklerin ve 2008 yılında Milli Eğitim Bakanlığı tarafından öğretmen yeterliklerinin belirlenmesinin, öğretmenlik mesleğine yönelik tutum, öğret- menlik mesleğini tercih nedenleri, özyeterlik algısı ve öğretmen yeterlikleri gibi konuların güncel olmasını sağladığı söylenebilir. Öğrenme konu alanına ilişkin frekans değerleri Tablo 12 'de verilmiştir.

Tablo 12. Öğrenme Konu Alanı

\begin{tabular}{lclc}
\hline Kategori & $\mathrm{f}$ & Kategori & $\mathrm{f}$ \\
\hline Öğrenme stratejileri & 10 & Ö̆̆grenme yaklaşımları & 4 \\
Öğrenme stilleri & 9 & Öğrenme ortamı-Sınıf atmosferi & 3 \\
Okuma-anlama stratejileri & 5 & Başarı yönelimi/faktörleri & 3 \\
Üstbiliş & 5 & Diğer & 13 \\
Özdüzenleme & 5 & & \\
\hline
\end{tabular}

Tablo 12'ye göre öğrenme konu alanı çerçevesinde en çok öğrenme stratejileri $(f=10)$, öğrenme stilleri $(\mathrm{f}=9)$, okuma-anlama stratejileri $(f=5)$, üstbiliş $(f=5)$, özdüzenleme $(f=$ 5) ve öğrenme yaklaşımları ( $\mathrm{f}=4)$ konuları çalışılmıştır. Buna göre, Türkiye `de 2005 yılında uygulamaya koyulan ve öğrenci merkezli TARTIŞMA VE ÖNERILLR

Bu araştırmada, Türkiye`de 2007-2011 yılları arasında "Eğitim Programları ve Öğretim (EPÖ)" alanında yayınlanmış makalelerin yayınlandığı yıl, yazar sayısı, yöntemi, veri toplama araçları, örneklem özellikleri, veri analiz teknikleri, konu alanları ve konuları açısından değerlendirilmesi ve EPÖ alanındaki araştırma eğilimlerinin belirlenmesi amaçlanmıştır. Bu amaç doğrultusunda şu sonuçlara ulaşılmıştır:

2007-2011 yılları arasında yayınlanan makalelerin yıllara göre dağılımı birbirine çok yakındır. Son üç yılda bir artış olduğu belirlense de makalelerin beş yıla dengeli bir şekilde dağıldı̆̆ı söylenebilir. Makalelerin büyük çoğunluğu (\% 84.7) iki yazarlı ya da tek yazarlıdır. Makalelerdeki yazar sayısı alandaki çalışma eğilimlerini belirlemek açısından önemli görülebilir. EPÖ alanındaki eğilim ikiden fazla yazarlı makale çalışmalarının az yapıldığı yönündedir. Bu duruma Türkiye deki akademik yükselme ve atanma kriterleri yaklaşımları benimseyen öğretim programlarının EPÖ alanında, öğrenme stratejileri, öğrenme stilleri, üstbiliş ve özdüzenleme gibi öğrenciler arasındaki bireysel farklıkların önemini vurgulayan konulara yönelik çalışmaların sayısını artırdığı söylenebilir.

nedeniyle akademisyenlerin kariyerlerine ilişkin kaygılarının da bir neden olduğu söylenebilir. Alper ve Gülbahar (2009) 20032007 yılları arasında “Turkish Online Journal of Educational Technology" (TOJET) 'te yayınlanan eğitim teknolojileri alanındaki makaleleri inceledikleri çalışmalarında makalelerin çoğunluğunun bir ya da iki yazarlı olduğu sonucuna ulaşmışlar ve bu durumu akademisyenler arasındaki işbirliği yetersizliği ve akademik kariyere ilişkin gereksinimler olarak açıklamışlardır. Arık ve Türkmen (2009) de Türkiye'de yayımlanmakta olan ve Social Science Citation Index (SSCI)'de taranan Eğitim Bilimleri ile ilgili dergilerde 2008 yılında yayınlanan makaleleri nitelik ve niceliğine göre değerlendirdikleri çalışmalarında makale başına 1,9 yazar düştüğü sonucuna ulaşmışlar ve bu durumu eğitim alanında araştırma yapanların ekip çalışmasına henüz yatkın olmadıkları şeklinde yorumlamışlardır.

Makalelerin büyük çoğunluğu (\% 89.5) araştırma-incelemeye dayalı makalelerdir. 
Erdem (2011) de 2005-2006 yıllarında Türkiye'deki eğitim alanında yayımlanan hakemli dergilerdeki 314 makaleyi değerlendirdiği araştırmasında makalelerin \%79'unun herhangi bir "araştırma yöntemli" makaleler olduğu, \%21 inin ise "düşünce-tartı̧ma" yazıları ya da "derleme" türü yazılar olduğu sonucuna ulaşmıştır. Araştırma-incelemeye dayalı makalelerin de büyük çoğunluğunda (\% 81.5) nicel yöntem kullanılmıştır. Erdem (2011) de çalışmasında Türkiye'de eğitim alanında yapılan bilimsel araştırmaların büyük çoğunluğunun (\% 82) nicel araştırma yöntemleri kullanılarak yapıldığını ortaya koymuştur. Chen ve Hirschheim (2004) de bilgi işlem sistemleri alanında yapilan makaleleri inceledikleri çalışmalarında makalelerin \% 60'ının nicel, \% 30'unun nitel ve \% 10 'unun ise karma yöntemli olduğunu belirlemişlerdir. Hranstinski ve Keller (2007), Guo ve Sheffiled (2008), Arık ve Türkmen (2009), Balcı ve Apaydın (2009), Karadağ (2009) ile Fazlıŏulları ve Kurul (2012) da çalışmalarında, makalelerde çoğunlukla nicel araştırma yönteminin kullanıldığını belirlemişlerdir. Yapılan araştırmaların büyük çoğunluğunda nicel yöntemin tercih edilmesi, karma yöntemlerin işe koşulmadığı ve dolayısıyla, makalelerin nicel ve nitel araştırma yöntemlerini tek başına kullanmanın getirdiği sınırlılıklardan kurtarılamadığını göstermektedir. Sözbilir ve Kutu (2008) da araştırmalarda çoklu yöntem ve veri toplama araçlarının kullanılmasıyla çalışmaların daha kaliteli olacağını, bunun da araştırma sonuçlarının geçerlik ve güvenirliklerini olumlu yönde etkileyeceğini belirtmişlerdir.

Makalelerin desenleri incelendiğinde ise en çok (\% 66.5) deneysel olmayan nicel desenlerin, en az (\% 0.9) ise etkileşimli olmayan nitel desenlerin kullanıldığı belirlenmiştir. Deneysel olan makalelerin büyük çoğunluğu (\% 84.3) yarı deneyseldir. Deneysel olmayan makalelerin büyük çoğunluğu (\% 90.3) ise betimsel tarama türündedir. Orlikowski ve Baroudi (1991), Farhoomand ve Drury (1999), Chen ve Hirschheim (2004), Erdoğan, Marcinkowski ve Ok (2009) ile Fazlığulları ve Kurul (2012) da çalışmalarında makalelerin çoğunlukla tarama türünde olduğu sonucuna ulaşmışlar ve nicel çalışmaların popülerliğini koruduğunu belirtmişlerdir. Araştırmaların büyük çoğunluğunda betimsel tarama modelinin tercih edilmesi var olan durumu ortaya koymanın ötesine gidilemediğinin bir göstergesi olabilir. Etkileşimli nitel desene sahip 16 makalenin 10 tanesi durum çalışması iken olgubilim ve eylem araştırması gibi etkileşimli nitel çalışmaların sayısının çok az olduğu, kuram oluşturma, kültür analizi ve eleştirel çalışma türlerinde ise herhangi bir çalışma bulunmadığı belirlenmiştir. Etkileşimli olmayan nitel çalışmalarda da sadece 3 makale bulunmaktadır. Bu açıdan özellikle meta analiz/değerlendirme, kavram analizi ya da tarihsel analiz türündeki çalışmalara oldukça ihtiyaç duyulduğu söylenebilir. Arık ve Türkmen (2009) de nitel araştırmaların daha fazla zaman alması nedeniyle daha az gerçekleştirildiğini belirtmişlerdir. Karma desene sahip 23 makalenin ise 20 'si nicel ve nitel veri toplama araçlarının aynı anda kullanıldığı çeşitleme türündedir. Açılayıcı ya da keşfedici türde karma çalışmalara da ihtiyaç duyulduğu söylenebilir.

Veri toplama araçlarına göre en çok anket ya da ölçekler kullanılmıştır. Erdoğan, Marcinkowski ve Ok (2009) da çevre eğitimine yönelik yapılan makaleleri inceledikleri çalışmalarında en çok anket veya ölçeklerin kullanıldığını belirlemişlerdir. Erdem (2011) incelediği makalelerde büyük oranda "dereceleme ölçeklerinin" kullanıldığını ikinci olarak da en çok anketlerin kullanıldığını belirtmiştir. Alper ve Gülbahar (2009) da benzer şekilde en çok sırasıyla ölçek, başarı testi ve anketlerin kullanıldığı sonucuna ulaşmışlardır. EPÖ alanındaki makalelerin çoğunlukla tarama türünde olması nedeniyle 
veri toplama aracı olarak da çoğunlukla anket ya da ölçeklerin kullanıldığı söylenebilir. Sert vd. (2012) araştırmalarda çoğunlukla anketlerin tercih edilmesinin en temel nedeni olarak, bu teknikle daha çok kişiye ulaşılabilmesi ve bu yöntemle veri toplama sürecinin uygulama süresi ve uygulama maliyetleri açısından daha ekonomik olmasını göstermişlerdir. Sert vd. (2012) ayrıca, bir anda çok miktarda veriye ulaşmayı sağlayacak veri toplama araçlarına yönelimin azalması gerektiğini de ileri sürmüşler ve araştırmalarda önemli olanın yalnızca veri toplamak değil, aynı zamanda güvenilir ve gerçekçi veriler toplamak olduğunu ifade etmişlerdir.

Örneklem grubuna göre en çok sırasıyla lisans öğrencileri (163 makale), öğretmenler (85 makale), ilköğretim 1-5 öğrencileri (42 makale) ve ilköğretim 6-8 öğrencileriyle (33 makale) çalışılmıştır. Okul öncesi öğrencileri, ortaöğretim öğrencileri, lisansüstü öğrenciler, yöneticiler, veliler, öğretim elemanları ve müfettişler örneklem alındığı çalışma sayısı ise nispeten daha azdır. Lisans öğrencileriyle dikkate değer ölçüde çok çalışma yapılması kolay ulaşılabilir olması, diğer örneklem grupları ile az sayıda çalışma olması ise bilimsel araştırma yapmak için gerekli izin alma süreçlerinin Türkiye de uzun ve zor olması ya da öğretim elemanlarının ders yüklerinin fazla olması nedeniyle bir bilimsel çalışmaya ayırdıkları zamanı olabildiğince aza indirmeyi tercih etmeleri ile açıklanabilir. Fazlığulları ve Kurul (2012) da eğitim bilimleri doktora tezlerini inceledikleri çalışmalarında tezlerin çoğunluğunun yükseköğretim öğrencilerine yönelik olduğu sonucuna ulaşmışlardır. Arık ve Türkmen (2009) de çalışmalarda daha çok üniversite öğrencilerinin örneklemi oluşturduğunu ve araştırmacıların ulaşılması kolay olduğu için üniversite öğrencilerini tercih ettiklerini, ayrıca eğitim araştırmalarının asıl hedefi olması gereken okul öncesi, ilköğretim ve ortaöğretim öğrencilerinin gereken izinlerin prosedürlerinin zorluğu ve zaman kaybı nedeniyle ihmal edildiğini belirtmişlerdir. Alper ve Gülbahar (2009) da makalelerin daha çok yükseköğretime yönelik olarak yapıldığını bunun nedeni olarak da izin almadaki zorluk gibi bürokratik engelleri belirtmişlerdir.

Örneklem büyüklüklerine göre ise en çok 3011000 arası (105 makale) kişi araştırma örneklemini oluşturmuştur. Tarama türü çalışmaların çoğunluğu oluşturduğu da düşünüldüğünde genel olarak çalışmalardaki örneklem büyüklüklerinin oldukça iyi olduğu söylenebilir. Genel olarak \% 5'lik belirlilik düzeyinde 30'dan büyük 500'den küçük örnek büyüklükleri pek çok araştırma için yeterlidir (Altunışık, Coşkun, Bayraktaroğlu ve Yıldırım, 2012). Alper ve Gülbahar (2009) da makalelerin çoğunda yüksek örneklem büyüklüklerine ulaşıldığını belirlemişlerdir.

Veri analiz tekniklerine göre incelendiğinde ise makalelerde en çok sırasıyla ortalama/standart sapma değerleri (239), t-testi (183), frekans/yüzde değerleri (140) ve ANOVA (138) şeklindedir. Nitel analiz tekniklerinden ise en çok (53 makale) içerik analizi tekniği kullanılmıştır. ANCOVA, Regresyon analizi, MANOVA, MANCOVA ve yapısal eşitlik modeli en az kullanılan analizlerdir. Nicel araştırma oranının çok yüksek olduğu bir alanda özellikle ANCOVA ve MANOVA gibi istatistiksel analiz tekniklerinin çok az kullanılması makalelerin bir eksikliği olarak yorumlanabilir. Arık ve Türkmen (2009) makalelerde en sık sırasıyla frekans ve yüzde değerleri, varyans analizi ve t-testinin kullanıldığını belirlemişlerdir. Hsu (2005) da eğitim araştırmalarında ençok betimleyici istatistikler ve ANOVA`nın kullanıldığı sonucuna ulaşmıştır. Erdem (2011) de benzer şekilde makalelerde en çok sırasıyla t-testi, ANOVA ve betimsel istatistiklerin kullanıldığını belirlemiştir. Ayrıca 
ANCOVA'nın kullanılması daha uygun olan deneysel çalışmalarda t-testinin tercih edildiğini, çok değişkenli analizlerin nadir olarak kullanıldığını, bu durumun da bir araştırma problemine ilişkin uygun tekniklerin seçilmesinden çok, araştırmacı tarafından bilinen istatistiksel tekniklere göre araştırma problemi oluşturulduğunu düşündürdüğünü belirtmiştir.

Makaleler konu alanlarına göre incelendiğinde ise en çok sırasıyla öğretme (95 makale), öğrenci-öğretmen özellikleri (69 makale) ve öğrenme (57 makale) konu alanlarında makale yayınlandığı belirlenmiştir. Eğitim programları ve öğretim alanının özellikleri ve kapsamı dikkate alındığında konu alanlarına göre dağılımın beklenildiği ölçüde olduğu söylenebilir. Ancak program değerlendirme, eğitim felsefesi, eğitim tarihi gibi EPÖ alanının temelini oluşturan alanlardaki makale sayılarının yeterli olmadığı söylenebilir. Öğretme konu alanı çerçevesinde en çok sırasıyla yapılandırmacılık, çoklu zekâ, soru sorma, işbirlikli öğrenme, probleme dayalı öğrenme, drama, grup çalışmaları ve dil öğretim yöntemleri konularının çalışıldığı; öğrenci-öğretmen özellikleri konu alanına ilişkin öğretmenlik mesleği tutum/tercih, özyeterlik algısı/inancı, öğretmen yeterlikleri, yansıtıcı düşünme becerisi ve medya okuryazarlığı konularının çalışıldığı; öğrenme konu alanı çerçevesinde ise öğrenme stratejileri, öğrenme stilleri, okuma-anlama stratejileri, üstbiliş, özdüzenleme ve öğrenme yaklaşımları konularının çalışıldığı belirlenmiştir. Tsai ve Wen (2005) ile Lee, Wu ve Tsai (2009) fen eğitimine yönelik makaleleri inceledikleri çalışmalarında en çok öğrenme ve öğretme konu alanlarında çalışmaların yapıldığını belirlemişlerdir.

Sonuçlar özetlenecek olursa, 2007-2011 yılları arasında EPÖ alanında yayınlanan makalelerin, genel anlamda, az yazarlılık, tek yöntemlilik (nicel ya da nitel), verilerin anket ve ya likert tipi ölçeklerle toplandığı, kolay ulaşılabilir örneklem gruplarının seçildiği, nispeten daha kolay istatistiksel tekniklerin yapıldığ çalışma alanı olarak da EPÖ’nün belirli alt alanlarının tercih edildiği tespit edilmiştir. $\mathrm{Bu}$ durum, araştırmacıların farklı boyutları olan, derinlikli araştırma konuları seçmediklerini, daha güvenilir veriler elde edilebilecek karma yöntemler, çoklu teknikler ve örneklem gruplarını tercih etmediklerini ve buna bağlı olarak da kolay istatistik teknikleri kullandıklarını göstermektedir. Buna göre araştırmacıların özgün çalışmalar yaparak bilime katkıda bulunmaktan ziyade akademik anlamda yükselmek için koşulları tamamlamaya yönelik çalıştıkları söylenebilir. Bu sonuçlara yönelik olarak aşağıdaki öneriler getirilebilir:

1. Araştırma problemleri uygun olduğu ölçüde, nicel ve nitel yaklaşımların bir arada kullanılarak sinırlılıklarını azaltan karma yöntemli çalışmaların sayısı artırılabilir.

2. Derinlemesine inceleme olanağ tür analizi, olgubilim, kuram oluşturma, eleştirel çalışma, eylem araştırması, kavram analizi, tarihsel analiz ve meta analizi gibi nitel çalışmaların sayısı artırılabilir.

3. Lisans öğrencilerinin dışında özellikle müfettişler, yöneticiler, öğretim elemanları, lisansüstü öğrenciler ve veliler gibi örneklem gruplarına yönelik çalışmaların sayısı artırılabilir.

4. Araştırma problemleri ve veri setlerinin özellikleri elverdiği ölçüde ANCOVA, MANOVA, MANCOVA ve yapısal eşitlik modeli gibi veri analiz tekniklerinin kullanılmasına özen gösterilebilir.

5. Eğitim programları ve öğretim alanının temelini oluşturan program değerlendirme, eğitim felsefesi ve eğitim tarihi gibi konu 
alanlarına yönelik çalışmaların sayısı artırılabilir.

6. Türkiye ve yurtdışında, eğitim programları ve öğretim alanındaki makaleler karşılaştırmalı olarak incelenebilir.
7. Eğitim programları ve öğretim alanındaki makaleler niteliksel açıdan incelenebilir.

\section{Kaynakça}

Alper, A. ve Gülbahar, Y. (2009). Trends and Issues in Educational Technologies: A Review of Recent Research in TOJET. The Turkish Online Journal of Educational Technology - TOJET, 8 (2), 124-135.

Altın, N. (2004). Ĕğitim Programları ve Öğretim Alanında Yapılan Yüksek Lisans Tezlerinin Analizi (Ankara, Gazi ve Hacettepe Üniversitesi). Yayımlanmamış yüksek lisans tezi, Ankara Üniversitesi Eğitim Bilimleri Enstitüsü, Ankara.

Altunışık, R., Coşkun R., Bayraktaroğlu, S. ve Yıldırım, E. (2012). Sosyal Bilimlerde Araştırma Yöntemleri (7. bask1). İstanbul: Sakarya Kitabevi.

Apaydın, S. (2009). 2000-2008 Yılları Arasında Türkiye`de Fizik Eğitimi Araştırmaları. I. Uluslararası Türkiye Ĕ̆itim Araştırmaları Kongresi, Çanakkale Onsekiz Mart Üniversitesi, Antalya.

Arık, R. S. ve Türkmen, M. (2009). Eğitim Bilimleri Alanında Yayımlanan Bilimsel Dergilerde Yer Alan Makalelerin İncelenmesi. I. Uluslararası Türkiye Eğitim Araştırmaları Kongresi, Çanakkale Onsekiz Mart Üniversitesi, Antalya.

Aydın, A., Erdağ, C. ve Sarıer, Y. (2010). Eğitim Yönetimi Alanında Yayınlanan Makalelerin Konu, Yöntem ve Sonuçlar Açısından Karşılaştırılması. Eurasian Journal of Educational Research, 39, 3758.

Aydın, A. ve Uysal, Ş. (2011). Türkiye'de ve Yurt Dışında Eğitim Yönetimi Alanında Yapılan Doktora Tezlerinin Konu, Yöntem ve Sonuçlar Açısından Değerlendirilmesi. Eurasian Journal of Educational Research, 42, 1-14.

Aypay, A., Çoruk, A., Yazgan, A. D., Kartal, O. Y., Tunçer, B., Attila, S. M. vd. (2010). Eğitim Yönetimi Araştırmalarının Durumu: Eğitim Yönetimi Dergilerinin Analizi, 1999-2007. Eurasian Journal of Educational Research, 39, 59-77.

Baki, A., Güven, B., Karataş, İ, Akkan, Y. ve Çakıroğlu, Ü. (2011). Trends in Turkish Mathematics Education Research: From 1998 to 2007. Hacettepe Üniversitesi Eğitim Fakültesi Dergisi, 40, 57-68.

Balıı, A. ve Apaydın, Ç. (2009). Türkiye'de Eğitim Yönetimi Araştırmalarının Durumu: Kuram ve Uygulamada Eğitim Yönetimi Dergisi Örneği. Kuram ve Uygulamada Eğitim Yönetimi Dergisi, 59(15), 325-343.

Bıkmaz, F., Aksoy, E., Tatar, Ö. ve Atak-Altınyüzük, C. (2010). Türkiye'de Program Geliştirme Alanında Yapılan Doktora Tezlerinin Çeşitli Değişkenler Açısından Analizi. 1. Ulusal Eğitim Programları ve Öğretim Kongresi, Balıkesir Üniversitesi, Ayvalık.

Chang, Y. H., Chang, C. Y. ve Tseng, Y. H. (2010). Trends of Science Education Research: An Automatic Content Analysis. Journal of Science Education and Technology, 19(4), 315-331.

Chen, W. \& Hirschheim, R. (2004). A Paradigmatic and Methodological Examination of Information Systems Research from 1991 to 2001. Information System Journal, 14, 197-235.

Cohen, L., Manion, L. ve Morrison, K. (2007). Research methods in education (6th ed.). New York: Routledge.

Çalık, M., Ünal, S., Coştu, B. ve Karataş, F. Ö. (2008). Trends in Turkish Science Education. Essays in Education, [Special edition] 23-45. 
Çiltaş, A., Güler, G. ve Sözbilir, M. (2012). Mathematics Education Research in Turkey: A Content Analysis Study. Educational Sciences: Theory \& Practice, 12 (1), 574-580.

Dunkin, M. J. (1996). Types of Errors in Synthesizing Research in Education. Review of Educational Research, 66 (2), 87-97.

Erdem, D. (2011). Türkiye'de 2005-2006 Yılları Arasında Yayımlanan Eğitim Bilimleri Dergilerindeki Makalelerin Bazı Özellikler Açısından Incelenmesi: Betimsel Bir Analiz. Eğitimde ve Psikolojide Ölçme ve Değerlendirme Dergisi, 2 (1), 140-147.

Erdoğan, M., Marcinkowski, T. ve Ok, A. (2009). Content Analysis of Selected Features of K-8 Environmental Education Research Studies in Turkey, 1997-2007. Environmental Education Research, 15 (5), 525-548.

Falkingham, L. T. ve Reeves, R. (1998). Context Analysis- a Tech-nique for Analysing Research in a Field, Applied to Literature on the Management of R and D at the Section Level. Scientometrics, 42 (2), 97-120.

Farhoomand, A. F. ve Drury, D. H. (1999). A Historiographical Examination of Information Systems. Communications of the Association for Information Systems, 1, 1-27.

Fazlıŏulları, O. ve Kurul, N. (2012). Türkiyedeki Eğitim Bilimleri Doktora Tezlerinin Özellikleri. Mehmet Akif Ersoy Üniversitesi Eğitim Fakültesi Dergisi, 24, 43-75.

Göktaş, Y., Hasançebi, F., Varışoğlu, B., Akçay, A., Bayrak, N., Baran, M. ve diğerleri. (2012a). Trends in Educational Research in Turkey: A Content Analysis. Educational Sciences: Theory \& Practice, 12 (1), 455-460.

Göktaş, Y., Küçük, S., Aydemir, M., Telli, E., Arpacık, Ö., Yıldırım, G. ve diğerleri. (2012b). Educational Technology Research Trends in Turkey: A Content Analysis of the 2000-2009 Decade. Educational Sciences: Theory \& Practice, 12 (1), 191-199.

Guo Z. VE Sheffield J. (2008). A Paradigmatic and Methodological Examination of Knowledge Management Research: 2000 to 2004. Decision Support Systems, 44, 673-688.

Gülbahar, Y. ve Alper, A. (2009). Öğretim Teknolojileri Alanında Yapılan Araştırmalar Konusunda Bir İçerik Analizi. Ankara Üniversitesi Ĕ̆itim Bilimleri Fakültesi Dergisi, 42 (2), 93-111.

Hranstinski, S. ve Keller, C. (2007). An Examination of Research Approaches That Underlie Research on Educational Technology: A Review from 2000 to 2004. Journal of Educational Computing Research, 36 (2), 175-190.

Hsu, T. (2005). Research Methods and Data Analysis Procedures Used by Educational Researchers. International Journal of Research \& Method in Education, 28 (2), 109-133.

İncekara, S. (2009). Uluslararası Alanda Coğrafya Eğitimi Araştırmaları ve Türkiye'den Örnekler: Mevcut Durum ve Gelecek Yönler. Doğu Coğrafya Dergisi, 21, 123-136.

Karadă̆, E. (2009). Eğitim Bilimleri Alanında Yapılmış Doktora Tezlerinin Incelenmesi. Ahi Evran Üniversitesi Ĕ̆itim Fakültesi Dergisi, 10 (3), 75-87.

Kayhan, M. ve Özgün-Koca, S. A. (2004). Matematik Eğitiminde Araştırma Konuları: 2000-2002. Hacettepe Üniversitesi Ĕ̆itim Fakültesi Dergisi, 26, 72-81.

Keselman, H. J., Huberty, C. J., Lix, L. M., Olejnik, S., Cribbie, L. A., Donauhe, B. vd. (1998). Statistical Practices of Educational Researchers: An Analyses of Their ANOVA, MANOVA, and ANCOVA Analyses. Review of Educational Research, 68 (3), 350-386.

Küçükoğlu, A., Taşgın, A., Ozan, C. ve Kaya, H. İ. (2011). Sınıf Öğretmenliği Lisansüstü Eğitim Uygulamalarına İlişkin Bir Araştırma. 10. Ulusal Sinıf Öğgetmenliği Ĕ̆itimi Sempozyumu, Cumhuriyet Üniversitesi, Sivas. 
Lee, M. H., Wu, Y. T. ve Tsai, C. C. (2009). Research Trends in Science Education from 2003 to 2007: A Content Analysis of Publications in Selected Journals. International Journal of Science Education, 31 (15), 1999-2020.

Orlikowski, W. ve Baroudi, J. J. (1991). Studying Information Technology in Organizations: Research Approaches and Assumptions. Information Systems Research, 2, 1-28.

Saracaloğlu, A. S. ve Dursun, F. (2010). Türkiye'de Eğitim Programları ve Öğretim Alanındaki Lisansüstü Tezlerinin İncelenmesi. 1. Ulusal Eğitim Programları ve Öğretim Kongresi, Balıkesir Üniversitesi, Ayvalık.

Sert, G., Kurtoğlu, M., Akıncı, A. ve Seferoğlu, S. S. (2012, Şubat). Öğretmenlerin Teknoloji Kullanma Durumlarını İnceleyen Araştırmalara Bir Bakış: Bir İçerik Analizi Çalışması. Akademik Bilişim Konferansı, Uşak Üniversitesi, Uşak.

Sözbilir, M. ve Kutu, H. (2008). Development and Current Status of Science Education Research in Turkey. Essays in Education [Special issue], 1-22.

Staton-Spicer, A. Q. ve Wulff, D. H. (1984). Research in Communication and Instruction: Categorization and Synthesis. Communicative Education, 33.

Şencan, H. (2005). Sosyal ve Davranışsal Ölçümlerde Güvenirlik ve Geçerlik. Ankara: Seçkin Yayıncılık.

Tarman, B., Güven, C. ve Aktaşlı, İ. (2011). Türkiye' de Sosyal Bilgiler Eğitimi Alanında Yapilan Doktora Tezlerinin Değerlendirilmesi ve Alana Katkıları. Selçuk Üniversitesi Ahmet Keleşoğlu Ĕ̆itim Fakültesi Dergisi, 32, 391-410.

Tavşancıl, E., Çokluk, Ö., Çıtak, G. G., Kezer, F., Yıldırım, Ö. Y., Bilican, S. vd. (2010). Eğitim Bilimleri Enstitülerinde Tamamlanmış Lisansüstü Tezlerin İncelenmesi (2000-2008). Ankara Üniversitesi Bilimsel Araştırma Projesi Kesin Raporu. acikarsiv.ankara.edu.tr/browse/6199/Binder1.pdf. Erişim tarihi: 10 Şubat 2012.

Tsai, C. C. ve Wen, L. M. C. (2005). Research and Trends in Science Education from 1998 to 2002: A Content Analysis of Publication in Selected Journals. International Journal of Science Education, 27, 3-14.

Ulutaş, F. ve Ubuz, B. (2008). Matematik Eğitiminde Araştırmalar ve Eğilimler: 2000 ile 2006 Yılları Arası. Illköğretim Online, 7 (3), 614-626.

Yıldırım, A. ve Şimşek, H. (2011). Sosyal Bilimlerde Nitel Araştırma Yöntemleri (8.baskı). Ankara: Seçkin Yayıncilik.

Yilmaz, K. ve Altınkurt, Y. (2012). An Examination of Articles Published on Preschool Education in Turkey. Educational Sciences: Theory E Practice, Special Issue, 3227-3241.

Yücedağ, T. ve Erdoğan, A. (2011). 2000-2009 Yılları Arasında Matematik Eğitimi Alanında Türkiye'de Yapılan Çalışmaların Bazı Değişkenlere Göre İncelenmesi. Gaziantep Üniversitesi Sosyal Bilimler Dergisi, 10 (2), 825-838. 


\section{Extended Abstract}

The purpose of this study is to find out research trends in the field of "curriculum and instruction" in Turkey by exploring the articles that were published between 2007 and 2011. For the purpose, articles were evaluated in terms of their publishing dates, number of authors, methods, data collection procedures, sample characteristics, data analysis techniques, subject areas and their topics.

This study is a descriptive research study. The articles were explored by investigating the documents within the framework of descriptive approach and research trends in the field of CI were attempted to be described. In the study, 24 journals that are published in the field of CI, which are all included in the ULAKBIM Database, were covered in the study. The study was limited to the years from 2007 to 2011. Amount these 24 journals, a total of 380 articles written either by the instructors working in the department of curriculum and instruction or by the instructors who had doctorate degrees were selected and investigated. Each article was subjected to descriptive and content analysis by using article rating form. The "Article Rating Form" was developed by Sözbilir and Kutu but the revised version of the form was used in this study. The validity of the revised version of the "Article Rating Form" was examined and validated by three professors (faculty members) in the field. The form basically consists of five sections: (i) Identification of the article, (ii) research design/method, (iii) data collection tools, (iv) sampling and (v) data analysis methods. Content analysis was used to analyze the gathered data. The results of the analysis were represented in frequency and percentage values.

Annual distribution of the articles published between the years 2007 and 2011 is very close to each other. Although it was found that there has been an increase in the last three years, it is still possible to state that the articles showed a balanced distribution in the last five years. The majority of the articles $(84.7 \%)$ were written either by a single author or two authors. The majority of the articles (89.5\%) are the studies that were based on research and investigation in most of which (81.5\%) quantitative research method was used. When the designs of the articles were investigated, it was found that non-experimental quantitative method was used mostly, while non-interactive qualitative research design was found to have been used by 0,9 percent. The majority of the experimental studies is semi-experimental by 84,3 percent. Most of the non-experimental studies were found to be descriptive surveys by 93 percent. While ten of the sixteen interactive design articles were case studies, it was found that the number of interactive qualitative studies such as phenomenology and action research studies was quite less and that there hadn't been any studies on grounded theory, cultural analysis and critical research models. And there are only three articles found about non-interactive qualitative studies. Among the data collection tools, questionnaires and scales were most commonly used methods in the studies. Sample groups of the articles were mostly university students (163 articles) followed by teachers ( 85 articles), primary school children from first grade to five (42) and primary school students from 6 grade to 8 (33 articles) respectively. The number of sample groups consisted of pre-school children, secondary school students, post graduates, administrators, parents, instructors and of inspectors was relatively less. The reason for the fact that there are considerable number of studies with university students might be that they are easily available and the reason for that there aren't many studies with other sample groups might be because it is rather difficult and it takes quite a long time to take necessary formal permissions in Turkey. Besides, because of their over course load at universities, the instructors prefer to lessen the time period of their 
studies as much as possible. In terms of the size of sample groups, utmost 301-1000 participants (105 articles) formed the sample groups. Considering that most of the studies were quantitative research studies, it is possible to state that the size of sample groups was quite good. When the articles were investigated according to their data analysis methods, they were mostly found to be mean/standard deviation values (239) followed by t-test (183), frequency/percentage values (140) and ANOVA (138), respectively. Among qualitative methods, content analysis was used most, while ANCOVA, regression analysis, MANOVA, MANCOVA and structural equality modeling were found to be the least used data analysis methods. The fact that in a field, in which the rate of quantitative research is very high, the number of statistical analysis methods is very low might be interpreted that the researchers have lack of information on such techniques.

When the articles were investigated in terms of the subjects they deal with, it was found that they were mostly about teaching (95 articles), student-teacher characteristics (69 articles) and learning (57 articles), respectively. Given the nature and the scope of the field of $\mathrm{CI}$, the distribution of the articles according to their subject areas can be considered to be at the expected level. However, the study suggests that the number of articles on the subject areas such as education philosophy, education history which form the essentials of CI is not sufficient. Within the extend of the 'teaching' subject area, constructivism, multiple intelligence, asking question, cooperative learning, problem based learning, group work and language teaching methods were the major areas that were studied respectively; as for the studies with the subject matter of "student teacher characteristics", attitudes/preferences of teaching profession, teachers sufficiency's, reflective thinking ability and media literacy were found to the major areas that were made a matter of research. Within the subject area of "leaning", it was found that 'learning strategies', 'learning styles', 'reading-understanding strategies', 'metacognition', 'self-regulation' and 'approaches to learning' were the major areas that were studied. 


\section{Ek 1. İncelenen Dergiler ve Makale Sayıları}

\begin{tabular}{|c|c|}
\hline Dergiler & Makale Sayısı \\
\hline Ahi Evran Üniversitesi Kırşehir Eğitim Fakültesi Dergisi & 37 \\
\hline Ankara Üniversitesi Eğitim Bilimleri Fakültesi Dergisi & 9 \\
\hline Atatürk Üniversitesi Sosyal Bilimler Enstitüsü Dergisi & 6 \\
\hline Çukurova Üniversitesi Eğitim Fakültesi Dergisi & 12 \\
\hline Çukurova Üniversitesi Sosyal Bilimler Enstitüsü Dergisi & 23 \\
\hline Değerler Eğitimi Dergisi & 5 \\
\hline Dumlupınar Üniversitesi Sosyal Bilimler Dergisi & 6 \\
\hline Eğitim ve Bilim & 41 \\
\hline Erzincan Eğitim Fakültesi Dergisi & 11 \\
\hline Elektronik Sosyal Bilimler Dergisi & 17 \\
\hline Fırat Üniversitesi Sosyal Bilimler Dergisi & 3 \\
\hline Gaziantep Üniversitesi Sosyal Bilimler Dergisi & 9 \\
\hline Hacettepe Üniversitesi Eğitim Fakültesi Dergisi & 26 \\
\hline İnönü Üniversitesi Eğitim Fakültesi Dergisi & 4 \\
\hline Kastamonu Üniversitesi Kastamonu Eğitim Dergisi & 30 \\
\hline Mehmet Akif Ersoy Üniversitesi Eğitim Fakültesi Dergisi & 8 \\
\hline Mersin Üniversitesi Eğitim Fakültesi Dergisi & 6 \\
\hline Milli Eğitim & 26 \\
\hline Mustafa Kemal Üniversitesi Sosyal Bilimler Enstitüsü Dergisi & 7 \\
\hline Ondokuz Mayıs Üniversitesi Eğitim Fakültesi Dergisi & 6 \\
\hline Pamukkale Üniversitesi Eğitim Fakültesi Dergisi & 11 \\
\hline Türk Eğitim Bilimleri Dergisi & 54 \\
\hline Türkiye Sosyal Araştırmalar Dergisi & 13 \\
\hline Uludağ Üniversitesi Eğitim Fakültesi Dergisi & 10 \\
\hline TOPLAM & 380 \\
\hline
\end{tabular}


Ek 2. Makale Sınıflama Formu

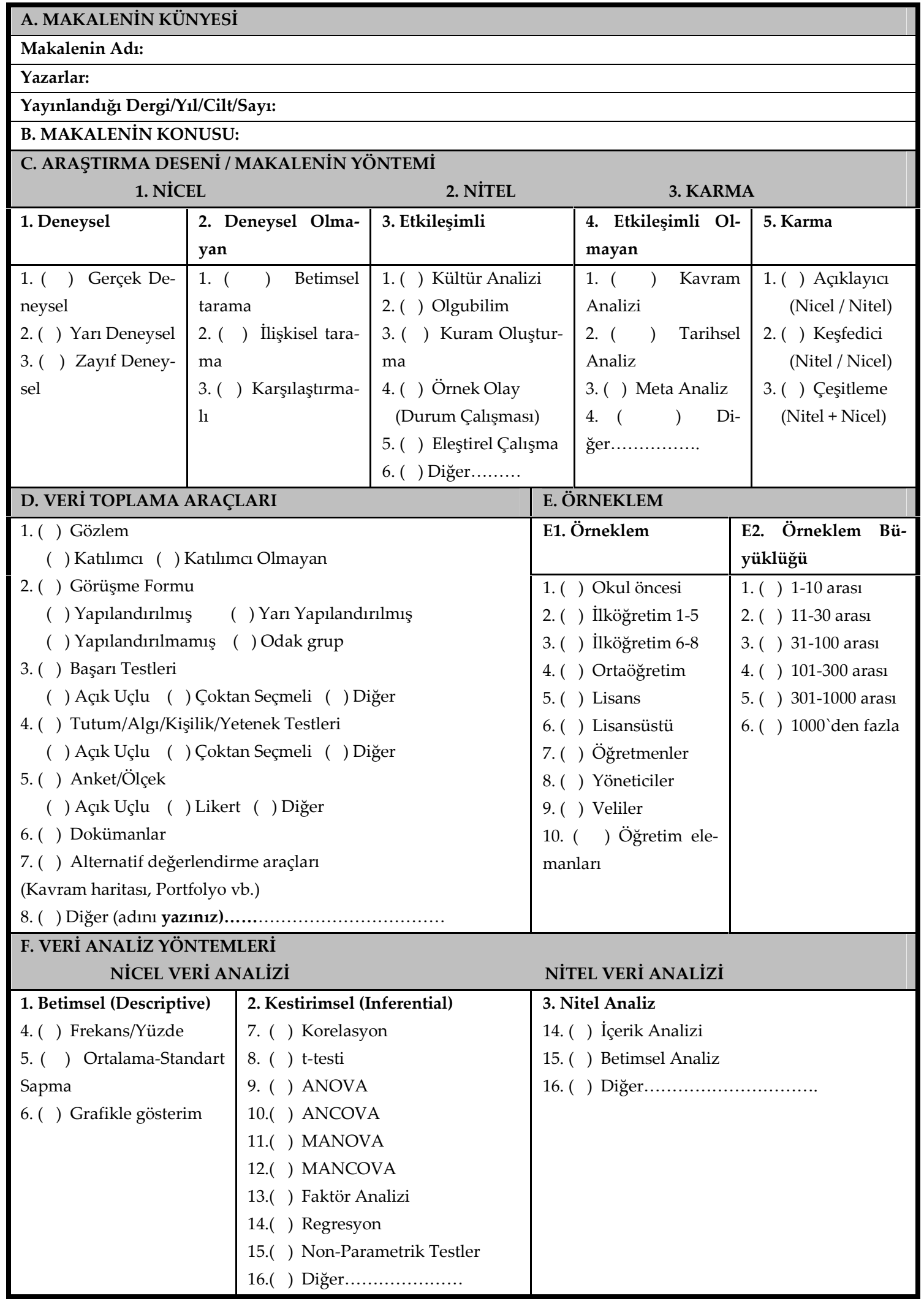

